\title{
ZNACZENIE TRANSFERU WIEDZY I EDUKACJI DLA ROZWOJU OBSZARÓW WIEJSKICH
}

Zarys treści: $W$ artykule podjęte zostały rozważania dotyczące możliwości transferu wiedzy i wykorzystania nowych form edukacji dla mieszkańców obszarów wiejskich. Głównym celem artykułu było wskazanie na znaczenie wiedzy i edukacji jako istotnych elementów rozwoju obszarów wiejskich. Tematyka wiedzy i edukacji niezmiennie się tu łączy, gdyż poprzez sprawne systemy edukacyjne gromadzimy wiedzę, którą następnie możemy przetwarzać, uzupełniać i kreować jej nowe zasoby.

Konstrukcję artykułu wraz z wprowadzeniem tworzy pięć części. Początkowo podjęto się analizy pojęcia i znaczenia wiedzy i jej dyfuzji dla rozwoju mieszkańców obszarów wiejskich. Następnie zbadano, jak zjawisko wiedzy i edukacji zostało opisane w wybranych dokumentach unijnych, z uwzględnieniem obszarów wiejskich. W kolejnej części zbadano to samo zagadnienie, ale w perspektywie wybranych dokumentów poziomu krajowego (również ze szczególnym uwzględnieniem obszarów wiejskich). W czwartej części omówiono wybrane, możliwe do zastosowania na obszarach wiejskich nowe formy kształcenia i transferu wiedzy. W ostatniej części zaprezentowano możliwe do zastosowania w procesie kształcenia i transferu wiedzy nowoczesne technologie informacyjne i podano przykłady ich zastosowania.

Artykuł przygotowany został w oparciu o analizę desk research danych wtórnych, głównie artykułów i publikacji krajowych oraz dokumentów urzędowych szczebla unijnego i krajowego nowego okresu programowania na lata 2014-2020. Analiza przeprowadzona została również wśród zasobów internetowych.

Słowa kluczowe: edukacja, obszary wiejskie, system dualny, transfer wiedzy, wiedza.

\section{Wprowadzenie}

W literaturze przedmiotu możemy wskazać na wiele definicji pojęcia „wiedza”. W najbardziej powszechnym rozumieniu jest to „ogół wiadomości zdobytych dzięki uczeniu się, zasób informacji i wiadomości z jakiejś dziedziny" (Stownik języka polskiego 1981, s. 700), a więc podkreśla rolę edukacji. G.J.B. Probst stwierdza, że wiedza to „ogół wiadomości i umiejętności wykorzystywanych przez jednostki do rozwiązywania problemów" (Probst i in. 2002, s. 35; zob. 
również: Beckmann, Beckmann 2009, s. 100), co zbieżne jest z definicją OECD, zgodnie z którą wiedza to „centralny element rozwoju gospodarczego, informacja, która może być przydatna i wykorzystywana do podejmowania racjonalnych decyzji ekonomicznych" (OECD 2001, s. 11). Podobnie jak definicje, wyróżnić można również wiele kategorii wiedzy. Przykładowy przegląd definicji oraz kategorii wiedzy znaleźć można w artykule: B. Piontek, P. Buczek (2014, s. 190-195). Jednakże niezmienne jest to, że warunkiem koniecznym powstawania wiedzy jest człowiek, który potrafi analizować informacje i wnioskować tworząc nową wiedzę.

Wiedza to zasób niematerialny i bardzo cenny, który może być gromadzony na różnych nośnikach. Zakłada się, że obejmuje m.in. kompetencje zasobów ludzkich i organizacji, zdolności wytwórcze, umiejętności wykorzystywane w procesach gospodarczych i innowacyjnych itp. (Dolińska 2010, s. 78). Jest ona niezwykle istotna $\mathrm{w}$ kontekście rozwoju jednostki, ale również przedsiębiorstw, czy całych gospodarek. Dość powszechne jest już pojęcie tzw. społeczeństwa wiedzy, które podkreśla niezwykle istotne znaczenie wiedzy w procesach wzrostu i rozwoju (Drucker 1994, s. 16). Wiedza i umiejętności jej efektywnego wykorzystania są bardzo cenne, zwłaszcza dla obszarów słabych pod względem potencjału własnego, a tereny wiejskie do takich należą.

W celu dyfuzji wiedzy realizowane są różne programy, głównie współfinansowane ze środków Unii Europejskiej (Klemens 2014, s. 42). Jej implementacja prowadzi do wytwarzania nowych zasobów wiedzy. Jednakże współcześnie dochodzi do szybkiego starzenia się wiedzy, dlatego tak istotne jest tworzenie możliwości do generowania nowych jej zasobów i edukowanie w obszarze kreatywnego i wielowymiarowego myślenia. Transfer wiedzy to jeden z elementów zarządzania wiedzą, obejmujący zbiór procesów umożliwiających tworzenie, upowszechnienie i wykorzystanie wiedzy w celu skutecznej realizacji zadań (Grudzewski, Hejduk 2004, s. 89). Zakłada się, że transfer wiedzy obejmuje dwa rodzaje działań - transmisję i absorpcję, gdzie transmisja to wysyłanie lub prezentowanie wiedzy potencjalnemu odbiorcy, a absorpcja to przyjęcie wiedzy w celu jej późniejszego wykorzystania (Jasińska-Biliczak 2014, s. 120).

Stopień tworzenia, dyfuzji i implementacji wiedzy zależy głównie od jakości i siły kapitału społecznego na danym terenie. Im silniejsze są więzi społeczne i gospodarcze, tym większa skłonność do dzielenia się różnego rodzaju zasobami, w tym również wiedzą. $\mathrm{W}$ tym kontekście, obszary wiejskie posiadają duży potencjał, wynikający z tradycji i silnych więzi lokalnych.

Polska wieś coraz aktywniej uczestniczy w ogólnoświatowym obiegu informacji i oddziałują na nią wzorce globalne, w tym również w kontekście transferu wiedzy i zmian edukacyjnych. Zmiany społeczno-gospodarcze na obszarach wiejskich są tak daleko idące, że aż 50\% młodzieży wiejskiej i 13\% młodzieży miejskiej deklaruje chęć zamieszkania na wsi. Z raportu przeprowadzonego na zlecenie Kancelarii Prezydenta Rzeczpospolitej Polskiej wynika, że podnosi się poziom wykształcenia ludności wiejskiej, a to przekłada się na 
poprawę materialnego standardu życia. Młodzież wiejska ma coraz bardziej rozbudzone aspiracje edukacyjne i materialne, akceptując współczesne wyzwania na rynku pracy dotyczące mobilności zawodowej i przestrzennej (Polska wieś 2012 ... 2012, s. 12; Nurzyńska, Poczta 2014).

Od ponad dekady młodzież wiejska trafia na uczelnie wyższe zdecydowanie większym strumieniem aniżeli w przeszłości (w 2011 roku 9,9\% mieszkańców wsi legitymowało się wykształceniem wyższym, podczas gdy w 2004 roku tylko 4,2\% - Nurzyńska, Poczta 2014, s. 50) na co wpływa głównie wzrost wartości wykształcenia w świadomości mieszkańców wsi, szersza oferta edukacyjna, łatwiejszy dostęp do miejsc na uczelni (mniej kandydatów na dane kierunki) ${ }^{1}$, czy lepsza sytuacja materialna rodzin. Okazuje się, że w tradycyjnych ośrodkach akademickich młodzież wiejska stanowi średnio $21 \%$ studiujących, a w nowych ośrodkach nawet do 35\% (Szafraniec 2012, s. 215). Niestety, coraz wyższe aspiracje w obszarze kształcenia wyższego związane są z decyzją o braku powrotu na wieś (Polska wieś 2012... 2012, s. 12), co negatywnie wpływa na proces transferu wiedzy na te tereny.

Co warte podkreślenia, wykształcenie pełni na obszarach wiejskich funkcję statusotwórczą, co uwidacznia się w silnym związku pomiędzy poziomem wykształcenia a pozycją społeczno-zawodową. Innymi słowy, tzw. „wyższa klasa średnia" ma najwyższy wskaźnik wykształcenia ( $2 / 3$ kategorii legitymuje się wykształceniem wyższym) (Halamska 2014, s. 89).

\section{Problematyka transferu wiedzy i kwestie edukacji na obszarach wiejskich w wybranych unijnych dokumentach strategicznych}

Jednym z najważniejszych dokumentów strategicznych poziomu unijnego jest Strategia na rzecz inteligentnego i zrównoważonego rozwoju sprzyjającego wtaczeniu społecznemu, w której wytypowano priorytety przewidziane do realizacji w perspektywie 2020 roku (Europa 2020, s. 11): a) rozwój inteligentny: rozwój gospodarki opartej na wiedzy i innowacji; b) rozwój zrównoważony: wspieranie gospodarki efektywniej korzystającej z zasobów, bardziej przyjaznej środowisku i bardziej konkurencyjnej; c) rozwój sprzyjający włączeniu społecznemu: wspieranie gospodarki o wysokim poziomie zatrudnienia, zapewniającej spójność społeczną i terytorialną.

W kontekście tematu artykułu najistotniejszy wydaje się priorytet pierwszy, w którym rozwój inteligentny rozumiany jest jako „zwiększenie roli wiedzy i innowacji jako sił napędowych przyszłego rozwoju". Będzie to możliwe do osiągnięcia poprzez realizację wzmożonych wysiłków w zakresie „podniesienia jakości edukacji, poprawy wyników działalności badawczej, wspieranie

${ }^{1}$ Zazwyczaj młodzież wiejska wybiera te uczelnie i kierunki, na które procedury rekrutacyjne nie są tak rygorystyczne. 
transferu innowacji i wiedzy w Unii i pełnego wykorzystania technologii informacyjno-komunikacyjnych oraz wprowadzenia do programów szkolnych elementów kreatywności, innowacji i przedsiębiorczości" (Europa 2020, s. 13 i 15). Zakłada się, że realizacja działań określonych w ramach tego priorytetu wpłynie na uwolnienie europejskiego potencjału, poprawi rezultaty procesu kształcenia oraz jakość i wyniki instytucji edukacyjnych (Europa 2020, s. 14). Istotny nacisk kładzie się na wspieranie partnerstwa w obszarze wiedzy pomiędzy światem nauki, biznesu, badań i innowacji (Europa 2020, s. 15) rozumiejąc, że generować to może znaczące korzyści dla gospodarki. Jednakże w odniesieniu do obszarów wiejskich Strategia Europa 2020 wskazuje dodatkowo na specjalne działania mające na celu wzmacnianie roli instrumentów UE wspierających innowacje „np. funduszy rozwoju obszarów wiejskich” (Europa 2020, s. 14).

W ramach każdego priorytetu realizowane są tzw. projekty przewodnie mające znaczący wpływ na osiągnięcie założonych celów (projekty przewodnie realizowane w ramach priorytetu I szczegółowo opisano w: B. Klemens (2013, s. 152-153) oraz B. Klemens (2014, s. 44-45). Niektóre z projektów w ramach priorytetu I finansowane będą przez Europejski Fundusz Społeczny (EFS), którego jednym $\mathrm{z}$ głównym celów jest inwestowanie $\mathrm{w}$ ludzi, a w sposób szczególny zwiększenie możliwości kształcenia w $\mathrm{UE}^{2}$. Rozporządzenie Parlamentu Europejskiego w sprawie EFS podnosi kwestię tworzenia lepszych warunków do tzw. life-long learning tak, aby umożliwić społeczeństwu przystosowanie się do nowych wyzwań we współczesnym świecie ${ }^{3}$. Działania służące podniesieniu jakości zasobów ludzkich w nowej perspektywie strategicznej, to m.in.: poprawa skuteczności i dostępności szkolnictwa wyższego; inwestowanie $\mathrm{w}$ edukację, umiejętności i wyrównywanie dostępu do uczenia się przez całe życie; lepsze dostosowanie systemów kształcenia i szkolenia do potrzeb rynku pracy; wspieranie rozwoju technologii i innowacji (por. art. 3 Rozporządzenia Parlamentu Europejskiego 1304/2013). Terytorialny charakter opisanej powyżej interwencji obejmuje m.in. obszary wiejskie.

Międzynarodowa Komisja ds. Edukacji dla XXI wieku wskazała tzw. cztery filary edukacji ${ }^{4}$ :

- uczyć się, aby wiedzieć: polega głównie na opanowaniu narzędzi wiedzy, a mniej na zdobyciu skodyfikowanych wiadomości, które szybko się dewaluują. „Poszerzanie wiedzy, która pozwala każdemu lepiej zrozumieć różnorodne aspekty jego otoczenia, służy rozbudzaniu zainteresowań intelektualnych

\footnotetext{
${ }^{2} \mathrm{http} / /$ ec.europa.eu/regional_policy/thefunds/social/index_pl.cfm(dostęp:28.12.2014).

${ }^{3}$ Rozporządzenie Parlamentu Europejskiego i Rady UE nr 1304/2013 z dnia 17 grudnia 2013 roku w sprawie Europejskiego Funduszu Społecznego i uchylające rozporządzenie Rady (WE) nr 1081/2006.

${ }^{4} \mathrm{http} / /$ www.unesco.pl/fileadmin/user_upload/pdf/4_Filary_Raport_Delorsa.pdf (dostęp: 10.01.2015).
} 
i krytycyzmu oraz umożliwia odkrywanie rzeczywistości dzięki niezależności sądów". Zakłada się, że proces uczenia się nigdy się nie zakończy i każde przeżyte doświadczenie może go wzbogacić;

- uczyć się, aby działać: to troska, jak nauczyć ucznia stosowania w praktyce nabytych umiejętności? Jak kształcić na potrzeby rynku, który stale ewoluuje? Jak przejść od poziomu kwalifikacji do poziomu kompetencji?;

- uczyć się, aby żyć wspólnie: to jedna z form przeciwdziałania szeroko rozumianej przemocy. Chodzi o kreowanie właściwych postaw wśród dzieci i młodzieży tak, aby przerwać łańcuch przemocy. Kładzie się tu istotny nacisk na jakość komunikacji i relacji międzyludzkich. Zakłada się, że edukacja powinna obrać dwie drogi: stopniowe odkrywanie innego oraz zaangażowanie się we wspólne projekty;

- uczyć się, aby być: „edukacja powinna przyczynić się do rozwoju każdej jednostki - umysł i ciało, inteligencja, wrażliwość, poczucie estetyki, osobista odpowiedzialność, duchowość". Chodzi o to, aby kształtować samodzielne i krytyczne myślenie, wydawać niezależne sądy, brać odpowiedzialność za swoje decyzje i aby w pełni się rozwijać poznając siebie samego. Proces ten trwa całe życie.

Ścieżki te przenikają się i uzupełniają. Jednakże tylko realizacja wszystkich czterech aspektów kształcenia stwarza edukacji szansę na całościowe spełnienie swojej misji. Próby urzeczywistnienia wszystkich czterech aspektów edukacji w kontekście rozwoju obszarów wiejskich odgrywać będą istotną rolę, gdyż wciąż jeszcze istnieją znaczące dysproporcje w poziomie edukacji pomiędzy mieszkańcami miasta i wsi.

\section{Problematyka edukacji i transferu wiedzy na obszarach wiejskich w dokumentach strategicznych poziomu krajowego}

Dokumentem strategicznym określającym priorytety i obszary wykorzystania funduszy unijnych (takich, jak: Europejski Fundusz Społeczny, Europejski Fundusz Rozwoju Regionalnego, Fundusz Spójności) w latach 2007-2013 były Narodowe Strategiczne Ramy Odniesienia (NSRO). Dokument ten w sposób szczególny podkreślał spójność społeczną budowaną na podstawie procesu przemian jakościowych i ilościowych na rzecz wyrównywania szans rozwojowych i wspomagania przemian strukturalnych na obszarach wiejskich, będąc w komplementarnym związku z Programem Rozwoju Obszarów Wiejskich na lata 2007-2013 (zob. Zadrożniak 2015, s. 339). Wśród celów horyzontalnych NSRO wymienić można m.in. poprawę jakości kapitału ludzkiego i zwiększenie spójności społecznej; wyrównywanie szans rozwojowych i wspomaganie zmian strukturalnych na obszarach wiejskich. 
W 2008 roku rozpoczęto realizację Programu rozwoju edukacji na obszarach wiejskich (PREOW), który trwał do 2013 roku. Cel strategiczny zdefiniowany został jako rozwój edukacji na wsi i obszarach wiejskich. Do celów operacyjnych Programu zaliczono m.in. poprawę jakości procesu kształcenia; rozszerzenie oferty edukacyjnej dla osób dorosłych i wspieranie kształcenia ustawicznego; aktywizowanie środowisk wiejskich do podejmowania działań o charakterze edukacyjnym, społecznym i kulturalnym; rozwój umiejętności wykorzystania komputera oraz Internetu w życiu codziennym obywatela i przedsiębiorcy.

Strategia rozwoju kapitatu ludzkiego (SRKL 2013) jest jedną z dziewięciu tzw. strategii zintegrowanych i jest spójna ze Strategia rozwoju kraju 2020. Głównym jej obszarem zainteresowań jest rozbudowa i podnoszenie jakości kapitału ludzkiego w Polsce, poprzez wykorzystanie nowatorskich rozwiązań dostosowanych do wieku mieszkańców ${ }^{5}$. W dokumencie tym nie ma bezpośrednich podziałów na ludność miejską i wiejską, dlatego też proponowane rozwiązania dotyczą ogółu populacji.

Zdefiniowanym w SRKL wyzwaniem w obszarze rozwoju kapitału ludzkiego jest m.in. rozwijanie wiedzy i podejmowanie pracy. Zakłada się, że do 2020 roku w ogólnej liczbie miejsc pracy będzie rosło zapotrzebowanie na pracowników wysoko wykwalifikowanych, a spadało na pracowników nisko kwalifikowanych. Stąd zmiany w systemie edukacji powinny być postrzegane szeroko, a w uczniach/studentach powinno się rozbudzić umiejętność ciągłego dostosowywania, a nawet zmieniania swoich kwalifikacji w ciągu kariery zawodowej (SRKL 2013, s. 11). Strategia zakłada, że szeroko i nowocześnie rozumiana edukacja tworzy równoważny związek kształcenia i szkolenia, czemu sprzyjać może m.in. powiązanie oferty edukacyjnej z praktyką (s. 42-43).

Korelację pomiędzy odpowiednim poziomem i jakością edukacji a zatrudnieniem ukazano również w kolejnym dokumencie strategicznym: Programie operacyjnym Wiedza-Edukacja-Rozwój 2014-2020 (PO WER 2014), gdzie wskazano na konieczność lepszego przygotowania uczniów do przyszłego zatrudnienia poprzez nabycie przez nich umiejętności praktycznych, kształcenie umiejętności matematycznych, cyfrowych i w zakresie języków obcych. Podkreśla się również potrzebę zwiększenia wykorzystania przez placówki edukacyjne innowacyjnych metod wspierających proces nauczania. Aby wzmagać transfer wiedzy niezbędne jest wzmocnienie współpracy pomiędzy szkołami/ uczelniami a przedsiębiorcami i partnerami społecznymi. Podkreślono również potrzebę wyrównywania dostępu do uczenia się przez całe życie dla osób dorosłych (PO WER 2014, s. 17-19).

${ }^{5}$ Strategia rozwoju kapitału ludzkiego opiera się na nowatorskiej koncepcji polegającej na budowaniu kapitału ludzkiego w pięciu etapach życia: 1) wczesne dzieciństwo, 2) edukacja szkolna, 3) edukacja na poziomie wyższym, 4) aktywność zawodowa, uczenie się dorosłych i rodzicielstwo, 5) starość. 
W Strategii zrównoważonego rozwoju wsi, rolnictwa i rybactwa na lata 2012-2020 (SZRWRiR 2012) podkreśla się, że ludność obszarów wiejskich charakteryzuje niekorzystna struktura wykształcenia, chociaż osoby młode posiadają umiejętności i determinację $\mathrm{w}$ dążeniu do zwiększania tego poziomu (s. 11-12). Zakłada się więc, że „mieszkańcy obszarów wiejskich będą posiadać szeroki dostęp do wysokiej jakości edukacji [i] zatrudnienia" (s. 17). Aby zrealizować tę wizję, zdefiniowano cel główny i pięć celów szczegółowych, z których każdy - przynajmniej w ograniczonym obszarze - nawiązuje do kwestii wiedzy, edukacji i innowacji (np. pierwszy zakłada „wzrost jakości kapitału ludzkiego, społecznego, zatrudnienia i przedsiębiorczości na obszarach wiejskich, drugi zakłada poprawę warunków życia na obszarach wiejskich oraz poprawę ich dostępności przestrzennej”).

Najczęściej wykorzystywane sformułowania w tym obszarze zastosowane w SZRWRiR brzmią: uczenie się przez całe życie; podnoszenie poziomu wykształcenia; rozwój i poprawa infrastruktury edukacyjnej; poprawa jakości i dostępności edukacji; podnoszenie umiejętności i kwalifikacji; doskonalenie zawodowe; rozwój i upowszechnianie wiedzy; rozwój doradztwa; upowszechnianie informacji; badania, rozwój badań; rozwój i poprawa infrastruktury naukowo-badawczej; upowszechnianie rozwiązań. Można więc założyć, że w kontekście wiedzy i edukacji na obszarach wiejskich kwestie te odgrywają najważniejszą rolę i będą przedmiotem działań szczegółowych.

W Programie rozwoju obszarów wiejskich na lata 2014-2020 (PROW 2014) wskazano na sześć priorytetów wspólnej polityki rozwoju obszarów wiejskich, z których pierwszy wprost nawiązuje do „ułatwiania transferu wiedzy i innowacji (...) na obszarach wiejskich", a drugi i szósty wskazują na promowanie innowacyjnych technologii i rozwoju gospodarczego na obszarach wiejskich.

Analizując zapisy dokumentów strategicznych poziomu krajowego w nowej perspektywie, w wielu z nich podkreśla się rolę wiedzy i innowacji, ich transferu oraz lepszej edukacji na obszarach wiejskich, upatrując $\mathrm{w}$ nich możliwości podniesienia jakości życia i poziomu przedsiębiorczości.

\section{Możliwe do zastosowania nowe formy ksztalcenia i transferu wiedzy wpływające na rozwój obszarów wiejskich}

Coraz głośniej podnosi się kwestię konieczności zmiany paradygmatu nauczania $^{6}$ wskazując, że współczesny system kształcenia dostosowany jest do potrzeb raczej gospodarki industrialnej (gdzie głównymi czynnikami wytwórczymi była praca i kapitał), a nie gospodarki opartej o wiedzę. Aktualny system kształcenia ukierunkowany jest na przygotowanie kapitału ludzkiego (rozumianego jako zasoby pracy), o wysokim stopniu myślenia odtwórczego,

\footnotetext{
${ }^{6}$ Zob. np.: http://www.ted.com/talks/ken_robinson_changing_education_paradigms (dostęp: 17.12.2014).
} 
mechanicznym wykonywaniu działań oraz niskim poziomie kreatywności, umiejętności samodzielnego zdobywania informacji i rozwiązywania problemów ${ }^{7}$.

Funkcjonujący wciąż jeszcze model kształcenia polegający na przekazywaniu wiadomości i umiejętności nie sprawdza się, ponieważ z natury swojej nie przewiduje czynnego zaangażowania ucznia $\mathrm{w}$ proces nauki ${ }^{8}$. W podejmowaniu działań społecznych i przedsiębiorczych pomaga raczej wykreowanie umiejętności myślenia dywergencyjnego, co jest rzadkim zjawiskiem w szkołach. Istnieje więc rozbieżność pomiędzy umiejętnościami, które nabywa uczeń polegającymi na odtwórczym „odgadywaniu” rozwiązań w zadaniach a potrzebami rynku, na którym preferowana jest kreatywność, myślenie samodzielne i wielokierunkowe, etyczne zachowanie, umiejętność pracy w grupie, rozwiązywanie konfliktów i przedsiębiorczość.

Analizując aktualnie podstawowe wyzwania edukacyjne zarysowują się pewne ogólne wnioski (na podstawie: Piontek, Buczek 2014, s. 200):

- coraz częściej praca i nauka ulegają zjednoczeniu, a więc skuteczna i wydajna praca zależą od permanentnego podnoszenia stanu wiedzy;

- nauka staje się procesem na całe życie;

- uczenie się nie jest już tożsame jedynie z nauką formalną;

- istnieje dysonans pomiędzy potrzebami rynku a tradycjami instytucji edukacyjnych;

- dzięki zastosowaniu nowych technologii miejsce nauki nie musi być przypisane do konkretnej przestrzeni fizycznej.

Rozpatrując zagadnienie dostępu do wiedzy i możliwości jej transferu wśród mieszkańców i przedsiębiorców działających na obszarach wiejskich warto uświadomić sobie fakt, że współcześnie obligatoryjnie należy uzupełniać i aktualizować wiedzę uzyskaną na konkretnych poziomach edukacji. Jest to zasób, który aktualnie bardzo szybko się dewaluuje. Aby sprawnie funkcjonować w tak szybko zmieniających się warunkach nie wystarczy, aby w początkowym okresie życia zgromadzić całą potrzebną wiedzę i czerpać z niej w nieskończoność.

${ }^{7}$ Walnie przyczynił się do tego system testów, w których największą liczbę punktów zdobywali uczniowie, którzy „wstrzelili się” w klucz rozwiązań. Kreuje to powielanie czyjegoś schematu myślenia i niweczy twórcze podejście.

${ }^{8}$ Znana jest sentencja Konfucjusza: „Powiedz a zapomnę; pokaż a zapamiętam; pozwól mi zrobić, a zrozumiem". W wydanej w 1946 roku publikacji Edgara Dale’a Audio-visual methods in teaching wskazano tzw. piramidę zapamiętywania. W artykule zaprezentowano efekty kilkutygodniowego doświadczenia, z którego wynika, że zapamiętujemy: ok. 10\% tego, co zostało przeczytane przez uczących się; ok. 20\% tego, co zostało przez nich wysłuchane; ok. 30\% tego, co uczący się zobaczyli; ok. 50\% tego co zobaczyli i usłyszeli; ok. 70\% tego o czym rozmawiali w twórczej dyskusji i ok. 90\% tego, czego uczyli innych (lub np. podczas odgrywania scenek sytuacyjnych). Interesujący wywód nt. wykorzystania piramidy Edgara Dale'a przeczytać można w publikacji A. Klej (2013). 
Jednostka powinna nabyć umiejętność aktualizowania, pogłębiania i wzbogacania podstawowej wiedzy ${ }^{9}$. To stąd tak silna presja w UE na kształcenie ustawiczne (tzw. long-life learning) oraz nieformalne i pozaformalne. Zakłada się wręcz, że całożyciowe uczenie się nie będzie domeną wyłącznie uprzywilejowanej części społeczeństwa, ale przymusem i koniecznością, niezbędną by prawidłowo funkcjonować w otaczającym świecie (Stalończyk 2014, s. 320-321).

Kształcenie ustawiczne jest coraz częściej przedmiotem debaty publicznej, ponieważ kreuje szeroko rozumiane możliwości w obszarze zaspokajania ambicji, samodoskonalenia i potrzeb edukacyjnych oraz uzupełniania wiedzy i kompetencji niezbędnych do jak najlepszego funkcjonowania na rynku pracy (por. Klemens 2013, s. 151-168). Przeprowadzone w 2011 roku badanie porównawcze w zakresie uczestnictwa w kształceniu ustawicznym mieszkańców poszczególnych państw europejskich ujawniło bardzo niski poziom tego wskaźnika dla Polski. W grupie wiekowej 25-64 lata średni udział Polaków w kształceniu ustawicznych w 2011 roku wyniósł 4,9\%, przy średniej unijnej w wysokości 8,9\% (Kwiatkowska-Ciotucha, Załuska 2014, s. 91). Jest to więc obszar, który wymaga wielu zmian w zakresie podniesienia jakości i dostępności tego typu usług oraz wzbudzenia $\mathrm{w}$ społeczeństwie świadomości potrzeby kształcenia ustawicznego.

Sekcja Rolnictwa, Rozwoju Wsi i Środowiska Naturalnego Europejskiego Komitetu Ekonomiczno-Społecznego wskazuje, że problemem dotyczącym zapewnienia na obszarach wiejskich w całej Europie ustawicznego kształcenia i szkolenia zawodowego należy się zająć na poziomie europejskim, krajowym i regionalnym (Opinia Sekcji rolnictwa... 2015). W celu poprawy jakości życia wiele młodych osób migruje z obszarów wiejskich do miast, co napędza negatywną spiralę gospodarczą i społeczną: mniejsza liczba ludności ogranicza liczbę pieniędzy w obiegu, co wpływa na rentowność lokalnych przedsiębiorców. Mało pieniędzy oznacza utratę usług medycznych, bankowych, edukacyjnych itp. Obszary wiejskie dostarczają zarówno żywność, jak i przestrzeń rekreacyjną, ale bez kompetentnych i dobrze wyszkolonych pracowników, lokalne przedsiębiorstwa mogą znacząco ograniczyć swoją działalność lub wręcz przestać funkcjonować. Zdolność przedsiębiorstw do funkcjonowania na obszarach o utrudnionych warunkach jest bardzo istotna $\mathrm{i}$ aby to osiągnąc pracodawcy potrzebują kompetentnych i dobrze wykwalifikowanych pracowników, co wymaga ściślejszej współpracy z pracodawcami oraz lokalnymi szkołami, technikami i uczelniami wyższymi. Dostęp do ustawicznego kształcenia i szkolenia zawodowego ma podstawowe znaczenie dla rozwijania działalności na własny rachunek, a na obszarach wiejskich może zaoferować specjalistyczne szkolenia w charakterystycznych dziedzinach, takich jak: rybołówstwo, leśnictwo, środowisko, rolnictwo itp. (Opinia Sekcji rolnictwa ... 2015).

\footnotetext{
${ }^{9} \mathrm{http}: / /$ www.unesco.pl/fileadmin/user_upload/pdf/4_Filary_Raport_Delorsa.pdf (do-
} stęp: 10.01.2015). 
Zakłada się, że kształcenie nieformalne, czy też pozaformalne prowadzone jest poza ustawowym formalnym systemem szkolnym ${ }^{10}$. Często wykorzystuje się w nim aktywne metody nauczania, dlatego też mówi się, że jest to uczenie się przez praktykę (Stalończyk 2014, s. 326). Pozaformalne uczenie się generuje duże korzyści głównie dlatego, że stanowi wyraz dążenia jednostki do samodoskonalenia się, co zdaje się być jednym z najsilniejszych bodźców motywacyjnych i stanowi o wysokim poziomie jej rozwoju.

Edukacja nieformalna lub pozaformalna może przyjmować różną formę, m.in.: Program Leonardo da Vinci, Program Comenius, Program Erasmus $+^{11}$, wycieczki, obozy naukowe, obozy przyrodnicze, obozy językowe, koła zainteresowań, uniwersytety trzeciego wieku, uniwersytety dziecięce, e-learning, kursy, szkolenia. Formy te dedykowane są również dla mieszkańców obszarów wiejskich, a możliwość skorzystania z nich uzależniona jest de facto - poza kwestiami finansowymi - od dostępności miejsca zamieszkania (infrastruktura drogowa i komunikacyjna) oraz od dostępności i jakości sieci internetowej.

Wsparcie kształcenia ustawicznego na terenach wiejskich było jednym z działań w ramach narodowego Programu rozwoju edukacji na obszarach wiejskich, podobnie jak tworzenie warunków do podejmowania przez uczniów nauki poza miejscem zamieszkania i eliminowanie barier dostępu do edukacji. W ramach Programu zrealizowano szereg działań, m.in. stworzono warunki ułatwiające szkołom na obszarach wiejskich aplikowanie w programach, takich jak m.in. Leonardo da Vinci lub Comenius; rozpoczęto proces wdrażania zmian w kształceniu zawodowym, których celem było podniesienie jakości i efektywności systemu kształcenia zawodowego i ustawicznego; udzielano wsparcia inicjatywom realizującym kształcenie „,na odległość”, w tym e-learning ${ }^{12}$; (zob. Sprawozdania z realizacji Programu rozwoju edukacji na obszarach wiejskich za lata: 2008-2012 dostępne na stronie internetowej Ministerstwa Edukacji Narodowej).

${ }^{10} \mathrm{Za}$ kształcenie pozaformalne uważa się udział $\mathrm{w}$ zorganizowanych działaniach edukacyjnych, prowadzonych poza formalnymi instytucjami szkolnymi. Zazwyczaj obejmuje dokształcanie i szkolenia (np. kursy, szkolenia, seminaria, prywatne lekcje) poza systemem szkolnym i nie wpływa na zmianę w poziomie wykształcenia. Można otrzymać zaświadczenie ukończenia np. kursu, ale nie jest to obligatoryjne. Natomiast kształcenie nieformalne rozumiane jest jako samodzielne uczenie się w celi uzyskania wiedzy lub udoskonalenia umiejętności. Powinno odbywać się poza zorganizowanymi formami edukacji szkolnej i pozaszkolnej (Ksztatcenie dorostych 2009)

${ }^{11}$ Od 1 stycznia 2014 roku Program Erasmus+ objął swoim zakresem działania wygasające programy, takie jak m.in. Program Młodzież w Działaniu (zob. http://www. mlodziez.org.pl/, dostęp: 15.01.2015), czy Program Grundtvig edukacja osób dorosłych (zob. http://www.grundtvig.org.pl/, dostęp: 15.01.2015).

${ }^{12}$ M.in. Centrum Doradztwa Rolniczego w Brwinowie prowadziło warsztaty dydaktyczne metodą e-learningową, w której w 2012 roku udział wzięło 906 rolników, nauczycieli i doradców rolnych. 
Jednakże edukacja pozaformalna - może nieco na przekór swojej nazwie uwzględniana będzie również w toku edukacji formalnej. Ministerstwo Nauki i Szkolnictwa Wyższego przygotowuje się do wprowadzenia uznawania efektów kształcenia się pozaformalnego i nieformalnego w edukacji wyższej. W założeniu, uczelnia zbada zdobyte w edukacji pozaformalnej przez kandydata bądź studenta kompetencje i na tej podstawie będzie mogła zapewnić dostęp do kształcenia formalnego lub zwolnienie z części wymagań programowych (zob. Urbanikowa 2010) $)^{13}$. Może to być bardzo atrakcyjna i skrócona forma zdobywania wykształcenia dla mieszkańców obszarów wiejskich, którzy często posiadają różne umiejętności praktyczne (np. w sektorze rolnym).

Nowelizacja ustawy Prawo o szkolnictwie wyższym zakłada, że wprowadzony zostanie podział uczelni na uczelnie o profilu ogólnoakademickim oraz o profilu praktycznym, w którym ponad połowa programu studiów obejmować będzie zajęcia praktyczne „kształtujące te umiejętności i kompetencje, które są prowadzone przez osoby posiadające doświadczenie zawodowe zdobyte poza uczelnią"14. Stwarza to możliwości dostosowania programu studiów i osiąganych efektów do wymogów rynku pracy, a z drugiej strony, niesie ze sobą potencjał do kariery naukowej dla praktyków.

Innym, bardzo ciekawym rozwiązaniem jest tzw. kształcenie dualne, które bardzo dobrze sprawdza się np. w Niemczech, Austrii czy Szwajcarii, a które w sposób szczególny może być atrakcyjne dla mieszkańców obszarów wiejskich. Kraje stosujące system dualny podnoszą, że jest on istotnym czynnikiem poprawy efektywności kształcenia, obniżenia poziomu bezrobocia wśród młodzieży, poprawy konkurencyjności przedsiębiorstw oraz wzrostu jakości i kultury pracy (Dziedziczak-Foltyn 2013, s. 50).

Kształcenie dualne, zwane inaczej naprzemiennym, polega na edukacji lub kształceniu łączącym okresy w instytucji edukacyjnej (lub centrum kształcenia) i w miejscu pracy. Schemat naprzemienny może mieć różny wymiar czasowy, np. tygodniowy, miesięczny lub roczny. Dosyć często uczestnicy kształcenia związani są z pracodawcą umową i otrzymują wynagrodzenie za swoją pracę (Dziedziczak-Foltyn 2013, s. 54).

System ten stwarza możliwości zdobycia kwalifikacji i kompetencji ważnych z punktu widzenia pracodawców i gospodarki regionalnej już w trakcie edukacji formalnej. Pożądana przez pracodawców struktura wiedzy, kompetencji i umiejętności pracowników definiuje stronę popytową rynku pracy, natomiast realne kwalifikacje pracowników tworzą podaż pracy. Równowagę na lokalnych

${ }^{13}$ W publikacji B. Klemens (2013, s. 156) wskazano, że: „Oznacza to np., że kandydat na studia wyższe, który wykaże się zdobytymi na rynku pracy i wymaganymi na dany kierunek studiów kompetencjami, będzie mógł uzyskać w toku studiów zwolnienie z części przedmiotów".

${ }^{14}$ Ustawa z dnia 27 lipca 2005 roku, Prawo o szkolnictwie wyższym (Dz.U., 2012, art. 2, pkt. 1, lit. 18ea z późn. zm.). 
i regionalnych rynkach pracy można osiągnąć poprzez jak najściślejsze dopasowanie struktury rzeczywistej do pożądanej (Bedrunka 2014, s. 158-159). Zgodnie ze wskazanym już modelem Dale'a, najlepsze efekty uczenia występują w rzeczywistych sytuacjach, kiedy trzeba podejmować decyzje w czasie rzeczywistym. Dlatego też w kontekście kadr regionalnych, najlepsze efekty kształcenia uzyskać można w sytuacjach pracy, a system dualny stwarza taką możliwość.

Pojęcie kształcenia dualnego kojarzone jest zazwyczaj z dwoma poziomami edukacji: zawodowym i wyższym. W przypadku szkolnictwa zawodowego korzenie systemu dualnego sięgają XIX wieku i wywodzą się z rzemiosła, ponieważ przedsiębiorstwa wciąż jeszcze czują się zobowiązane do przyjmowania adeptów zawodu na praktyki (Kwiatkiewicz 2006). Korzyści z takiego rozwiązania osiąga zarówno uczeń (m.in. praktyczne wykształcenie w zawodzie, nierzadko wynagrodzenie, bardzo często stanowisko pracy po zakończeniu procesu edukacji), jak i pracodawca (m.in. relatywnie niewielki koszt utrzymania pracownika, transfer wiedzy i innowacji z sektora edukacji).

Podwaliny kształcenia dualnego w szkolnictwie wyższym położyła nowelizacja ustawy Prawo o szkolnictwie wyższym, poprzez wprowadzenie wskazanego już profilu kształcenia praktycznego. Pierwsze próby jego implementacji do edukacji wyższej w kraju podjęto $\mathrm{w}$ województwie opolskim jako propozycja jednego z działań w ramach tzw. Programu Specjalnej Strefy Demograficznej ${ }^{15}$. Również w przypadku edukacji wyższej korzyści są osiągane dla obu partnerów ${ }^{16}$.

Jednostka badawcza Dyrekcji Generalnej Parlamentu Europejskiego, której zadaniem jest zapewnianie technicznej wiedzy fachowej na potrzeby m.in. Komisji Rolnictwa i Rozwoju Wsi oraz Komisji Kultury i Edukacji publikowała w 2014 roku poradnik Dualny system kształcenia: rozwiąanie na trudne

${ }^{15}$ W 2014 roku Akademicki Inkubator Przedsiębiorczości Uniwersytetu Opolskiego realizował projekt „PWP Dualne specjalistyczne szkolenia kadr dla regionu” i w jego ramach m.in. podjęto się opracowania i wdrożenia postaw modelu dualnej edukacji zawodowej w województwie opolskim, http:/www.firmyrodzinne.pl/sites/default/files/ szkolimy_dualnie.pdf (dostęp: 15.01.2015). Dodatkowo, dla poziomu edukacji wyższej realizowany jest projekt „Wdrożenie dualnego systemu kształcenia na Uniwersytecie Opolskim”, który zakłada m.in. utworzenie pilotażowych kierunków studiów dualnych (początkowo na kierunkach: filologia, inżynieria środowiska, ochrona środowiska, odnawialne źródła energii) - informacje uzyskane w biurze projektu w Akademickim Inkubatorze Przedsiębiorczości Uniwersytetu Opolskiego w 2014 roku.

${ }^{16} \mathrm{~Np}$. w Hochschule Baden-Württemberg (DHBW) w Niemczech studenci już od pierwszego dnia studiów zyskują samodzielność finansową. Jako pracownicy przedsiębiorstw uczestniczących w kształceniu, przez cały okres studiów otrzymują miesięczne wynagrodzenie. Przedsiębiorcy mają za to dostęp do najnowszej wiedzy teoretycznej z danego zakresu, posiadają ułatwiony kontakt do sektora nauki, mogą realizować wspólne projekty itp. 
czasy?, w którym m.in. wskazała powody, dla których część państw członkowskich decyduje się wdrożyć dualne systemy kształcenia oraz jakie są tego korzyści ${ }^{17}$.

Tradycyjnie uważa się, że mieszkańcy obszarów wiejskich są mocno ukierunkowani na działania praktyczne, zdobycie zawodu i utrzymanie rodziny. System dualny stwarza im dużą szansę w różnych aspektach: pozwala skracać czas trwania studiów, niesie ze sobą możliwość zarabiania podczas kształcenia się, daje praktyczną wiedzę uzupełnioną o założenia teoretyczne, pozwala poznać wykorzystywane przez przedsiębiorców technologie i ułatwia transfer wiedzy $i$ innowacji na obszary wiejskie.

\section{Możliwe do zastosowania w procesie kształcenia i transferu wiedzy nowoczesne technologie informacyjne mogące mieć zastosowanie na obszarach wiejskich}

Pomimo, że dostęp do konwencjonalnych form edukacji mieszkańców na obszarach wiejskich jest trudniejszy aniżeli mieszkańców miast, to przecież nie wyczerpuje to katalogu możliwości, które otwiera świat wirtualny. Można założyć, że dysproporcje te niwelują się dzięki dostępowi do Internetu i korzystania z narzędzi dostępnych on-line. Innymi słowy, możliwości uzupełnienia wiedzy przez mieszkańców obszarów wiejskich w dużym stopniu zależą od dostępności sieci internetowej, niezależnie czy korzystają oni z komputerów stacjonarnych, czy też urządzeń mobilnych ${ }^{18}$.

Mikro i małe przedsiębiorstwa na obszarach wiejskich przyznają, że uczenie się przez całe życie oraz walidacja umiejętności i kwalifikacji zdobytych w ramach uczenia się pozaformalnego i nieformalnego pomaga pracownikom i firmom rozwijać i wprowadzać dodatkowe technologie oraz oszczędzać czas i koszty dojazdów do szkoleń „miejscowych” (Opinia Sekcji rolnictwa... 2015).

Niestety, przeprowadzone w 2012 roku badanie wskazało, że tylko 18\% Polaków posiada wysokie umiejętności posługiwania się komputerem, tzn. że potrafi wykonać 5 lub 6 czynności związanych z obsługą komputera. Wynik ten plasuje Polskę na trzecim miejscu od końca wśród państw UE (por. Kupidura 2014, s. 125). Wydaje się więc, że priorytetowym działaniem powinno być polepszenie umiejętności obsługi komputera.

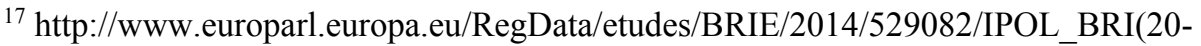
14)529082_PL.pdf (dostęp: 08.09.2015).

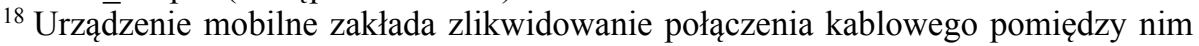
a siecią komputerową. Nie jest to jednak tak oczywiste. W rzeczywistości istnieją cztery warianty przyłączenia użytkownika mobilnego do sieci: - stacjonarnie i przyłączony przewodowo, - stacjonarnie i przyłączony bezprzewodowo, - mobilnie i przyłączony przewodowo (zastosowania specjalne i raczej niecywilne), - mobilnie i przyłączony bezprzewodowo (Piecuch 2014, s. 35).
} 
Poniżej krótki przegląd wybranych technologii informacyjnych, dedykowanych pogłębianiu i transferowi wiedzy, z których mogą korzystać (również) mieszkańcy obszarów wiejskich w procesie edukacji formalnej, nieformalnej bądź pozaformalnej. Rolą autorki nie było wskazanie pełnego katalogu takich narzędzi, a jedynie próba uzmysłowienia, jak szeroki jest ich wachlarz. Wskazano tu narzędzia, które nie wymagają specjalistycznej wiedzy i mogą być wykorzystane niemal „od zaraz” (bardziej szczegółowy katalog narzędzi zawarty został w publikacji: W. Furmanek (2014, s. 113-126):

- e-learning, to nauczanie z wykorzystaniem sieci komputerowych i Internetu. Nazywany jest również uczeniem na odległość, gdyż brak w nim bezpośredniego kontaktu z nauczycielem, a jego rolę przejmuje komputer. Nauczanie na odległość stwarza szansę zwiększenia możliwości kształcenia ustawicznego na obszarach wiejskich (dobrym przykładem był realizowany w latach 20082011 w 11 państwach członkowskich UE projekt E-ruralnet, którego celem było zbudowanie transeuropejskiej sieci na rzecz promocji kształcenia ustawicznego na obszarach wiejskich wspieranego nowoczesnymi technologiami informatycznymi. Więcej informacji: www.e-ruralnet.eu; zob. też: A. Pokorska, A. Kaleta (2012);

- portale edukacyjne będące platformą informatyczną, gromadzącą i przetwarzającą informacje $\mathrm{z}$ zakresu problematyki szkoły, edukacji, kursów. Służą dzieleniu się informacjami z określonych zagadnień. Można znaleźć na nich materiały dydaktyczne służące nauczaniu i uczeniu się. Do przykładowych portali z tego obszaru należą: Interkl@sa.pl, CEO.org.pl, Edunews.pl, Eduinfo.pl, Edustore.pl. Przykładem portalu zajmującego się realizacją badań naukowych i innowacji na obszarach wiejskich w okresie 2014-2020 jest portal Eip-Agri Agriculture and Innovation (www.eip-agri.eu);

- korepetytor edukacyjny to program, który jest instalowany na komputerze użytkownika bądź dostępny on-line, który służy jego indywidualnemu uczeniu się. Cechą charakterystyczną jest dostosowywanie się programu do postępów użytkownika w procesie uczenia się (funkcja korepetytora). Wiedza przekazywana jest partiami, a następnie użytkownik udziela odpowiedzi na zadane przez system pytania;

- wirtualne wycieczki dydaktyczne pozwalają użytkownikowi na poruszanie się po danym obiekcie czy też terenie. Funkcje multimedialne stwarzają możliwość uzupełnienia prezentacji o zdjęcia, filmy, dźwięk itp. Bardzo często małe przedmioty można obejrzeć w wymiarze 3D, a w przypadku obiektów odległych zastosować gigapanoramy. Ciekawym przykładem wirtualnej wycieczki dydaktycznej na obszary wiejskie jest wirtualny spacer po Geoparku Krajowym Góra św. Anny (projekt „Poznaj Geopark Krajowy Góra św. Anny” został współfinansowany ze środków PROW 2007-2013, http://geopark-goraswanny.pl/ cms_geopark/spacer/); 
- komputerowe gry symulacyjne, czy dydaktyczne (przykładem może być gra dydaktyczna opracowana do projektu E-ruralnet, http://www.e-ruralnetgame. net/);

- streaming umożliwia w czasie rzeczywistym dostarczenie cyfrowego przekazu do Internetu i jego odbiór przez użytkownika. Wykorzystywany jest m.in. do przekazywania wykładów (odbywających się w czasie rzeczywistym), prelekcji, szkoleń. Użytkownik otrzymuje link do streamingu i o odpowiedniej porze może uczestniczyć w wydarzeniu;

- ogólnodostępne wykłady umieszczane na platformach internetowych, np. w portalu youtube (z opcji tej korzystają niektóre instytucje publiczne, np. PARP. Ciekawą propozycją są Europejskie Wykłady Otwarte użytkownika Polska w UE, podczas których poruszane są m.in. zagadnienia transferu wiedzy, informacje o dotacjach, informacje o funduszach europejskich na rzecz rozwoju obszarów wiejskich).

Poza potencjałem, z którego można korzystać (zasoby wiedzy dostępne w sieci) należy również uzmysłowić mieszkańcom, że wpływ na ich wiedzę ma jakość źródeł, z których pozyskują informacje. Wydaje się więc, że ważne są działania uświadamiające $\mathrm{w}$ tym obszarze.

\section{Wnioski}

Możemy założyć, że wiedza jest zasobem strategicznym dla rozwoju obszarów o niskim potencjale endogenicznym, w tym dla obszarów wiejskich. Dlatego tak istotne jest, aby mieszkańcy i przedsiębiorcy funkcjonujący na wsi zdobywali ją lub tworzyli, gromadzili, przetwarzali i pielęgnowali. Na stopień tworzenia, dyfuzji i implementacji wiedzy duży wpływ ma jakość i siła kapitału społecznego na danym terenie. Obszary wiejskie, dzięki tradycji i silnym więzom lokalnym posiadają duży potencjał do dzielenia się różnego rodzaju zasobami, w tym również wiedzą.

Podkreślić należy, że polska wieś coraz aktywniej uczestniczy w ogólnoświatowym obiegu informacji i transferze wiedzy. W odniesieniu do kapitału ludzkiego $\mathrm{w}$ dokumentach strategicznych poziomu krajowego podkreśla się w sposób szczególny takie aspekty, jak: uczenie się przez całe życie, podnoszenie poziomu wykształcenia, podnoszenie umiejętności i kwalifikacji, poprawę jakości i dostępności edukacji.

W analizowanych dokumentach strategicznych poziomu unijnego i krajowego podkreśla się konieczność ułatwienia dostępu do wiedzy i edukacji dla mieszkańców obszarów wiejskich po to, aby wyrównywać szanse rozwojowe i tworzyć kadry zdolne do działań kreatywnych i innowacyjnych.

W ogólnym nurcie ukierunkowania na łączenie praktyki z nauką coraz głośniej podnosi się kwestię konieczności zmiany paradygmatu nauczania, wskazując, że współczesny system kształcenia nie jest dostosowany do potrzeb 
gospodarki opartej o wiedzę. Aby sprostać współczesnym wyzwaniom wymagane jest raczej pobudzanie myślenia kreatywnego i dywergencyjnego, a nie odtwórczego i mechanicznego. Niestety, występuje znacząca rozbieżność pomiędzy umiejętnościami, które nabywa uczeń/student a potrzebami rynku.

Ponieważ wiedza jest zasobem, który bardzo szybko się dezaktualizuje, warto uświadamiać mieszkańców obszarów wiejskich, że współcześnie obligatoryjnie należy uzupełniać i aktualizować wiedzę uzyskaną na konkretnych poziomach edukacji.

Istnieje wiele możliwości uzupełniania wiedzy, które mogą być atrakcyjne i dostępne dla mieszkańców wsi, m.in. poprzez kształcenie formalne, nieformalne i pozaformalne. Można wykorzystać edukacyjny system dualny, który łączy w sobie naukę tradycyjną z praktyczną znajomością zawodu. Ponieważ tradycyjnie uważa się, że mieszkańcy obszarów wiejskich są mocno ukierunkowani na działania praktyczne, zdobycie zawodu i utrzymanie rodziny, dlatego takie rozwiązanie jest dla nich bardzo korzystne. Innym potencjałem jest wykorzystanie tworzonej możliwości uznawania efektów kształcenia się pozaformalnego i nieformalnego w edukacji wyższej, co może np. skrócić czas studiów. Można skorzystać również z szerokiego wachlarza narzędzi internetowych: e-learningu, portali edukacyjnych, korepetytorów edukacyjnych, gier symulacyjnych i dydaktycznych, czy tzw. streamingu (przykłady ich wykorzystania na obszarach wiejskich zostały zaprezentowane w artykule).

Formy te dedykowane są również dla mieszkańców obszarów wiejskich, a możliwość skorzystania z nich uzależniona jest de facto - poza kwestiami finansowymi - od dostępności miejsca zamieszkania (infrastruktura drogowa i komunikacyjna) oraz od dostępności i jakości sieci internetowej. I tu warto podkreślić, że dostęp do dobrej jakości łącz internetowych stwarza mieszkańcom obszarów wiejskich szerokie możliwości uzupełniania wiedzy i kompetencji.

\section{LITERATURA}

Beckmann M., Beckmann G., 2009, Ksztattowanie spoleczeństwa wiedzy, [w:] Poskrobko B. (red.), Wplyw idei zrównoważonego rozwoju na politykę państwa i regionów, Wydawnictwo WSE, Białystok.

Bedrunka K., 2014, Kształcenie dualne w województwie opolskim jako odpowiedź na potrzeby przedsiębiorstw, ,Barometr regionalny. Analizy i prognozy”, 12(2), Wyższa Szkoła Zarządzania i Administracji w Zamościu.

Dale E., 1946, Audio-visual methods in teaching, Dryden Press, Nowy Jork.

Dolińska M., 2010, Innowacje w gospodarce opartej na wiedzy, PWE, Warszawa.

Drucker P.F., 1994, The age of social transformation, „The Atlantic Monthly”, 11.

Dziedziczak-Foltyn A., 2013, Ksztatcenie zawodowe $i$ kształcenie dualne $w$ Polsce $i$ województwie tódzkim. Stan obecny i perspektywy rozwoju. Analiza danych zastanych, Łódź.

Furmanek W., 2014, Wybrane technologie informacyjne dla edukacji - zarys problematyki, „Edukacja-Technika-Informatyka”, 2, Uniwersytet Rzeszowski, Rzeszów. 
Grudzewski W.M., Hejduk I.K., 2004, Zarządzanie wiedza w przedsiębiorstwach, Wydawnictwo Difin, Warszawa.

Halamska M., 2014, Struktura społeczna współczesnej polskiej wsi. Zróżnicowanie regionalne, [w:] „Wieś i Rolnictwo”, 1(162).

Jasińska-Biliczak A., 2014, Transfer wiedzy w regionie - wyzwanie dla nauki, ekonomii i przedsiębiorczości regionu, „Barometr regionalny. Analizy i prognozy”, 12(2), Wyższa Szkoła Zarządzania i Administracji w Zamościu.

Klej A., 2013, Wykorzystanie potencjatu interaktywnych technologii w procesie dydaktycznym w oparciu o audiowizualna metodę uczenia się Edgara Dale 'a, „E-mentor”, 4(51), Dwumiesięcznik Szkoły Głównej Handlowej w Warszawie.

Klemens B., 2013, Problematyka rozwoju obszarów wiejskich $w$ dokumentach strategicznych w perspektywie 2020 (ze szczególnym uwzględnieniem województwa opolskiego), [w:] Heffner K. (red.), Rozwój obszarów wiejskich w Polsce a polityka spójności Unii Europejskiej: stare problemy $i$ nowe wyzwania ze szczególnym uwzględnieniem woj. opolskiego, „Studia KPZK PAN”, 154, Warszawa.

Klemens B., 2014, Koncepcja klastrów a zagadnienia transferu wiedzy w perspektywie 2014-2020, „Barometr regionalny. Analizy i prognozy”, 12(2), Wyższa Szkoła Zarządzania i Administracji w Zamościu.

Ksztatcenie dorostych, 2009, GUS, Warszawa.

Kupidura T., 2014, Technologie informacyjno-komunikacyjne w projektach międzynarodowych wspierajacych rozwój kompetencji cyfrowych, „Edukacja Ustawiczna Dorosłych", 3(86).

Kwiatkiewicz A., 2006, Edukacja zawodowa w niemieckim systemie dualnym, „E-mentor", 1(13), Dwumiesięcznik Szkoły Głównej Handlowej w Warszawie.

Kwiatkowska-Ciotucha D., Załuska U., 2014, Możliwości otwarcia się uczelni na ksztatcenie ustawiczne, „Studia i Prace Wydziału Nauk Ekonomicznych i Zarządzania”, 36, Uniwersytet Szczeciński, Szczecin.

Nurzyńska I., Poczta W. (red.), 2014, Polska wieś 2014. Raport o stanie wsi, Wydawnictwo Naukowe Scholar, Warszawa.

OECD, 2001, Knowledge management in learning society, Paris.

Piecuch A., 2014, Edukacja coraz bardziej mobilna, „Edukacja-Technika-Informatyka”, 2, Uniwersytet Rzeszowski, Rzeszów.

Piontek B., Buczek P., 2014, Integracja wiedzy i edukacji i jej znaczenie dla zarzadzania rozwojem społeczno-gospodarczym, „Nierówności Społeczne a Wzrost Gospodarczy", 39(3).

Pokorska A., Kaleta A., 2012, E-learning na obszarach wiejskich Polski, [w:] „Kultura i Edukacja”, 3(89).

Polska wieś 2012. Potencjał obszarów wiejskich szansą rozwoju, 2012, Kancelaria Prezydenta Rzeczpospolitej Polskiej, Warszawa.

Probst G.J.B., Raub S., Romhardt K., 2002, Zarzadzanie wiedza w organizacji, Oficyna Ekonomiczna, Oddział Polskich Wydawnictw Profesjonalnych, Kraków.

Słownik języka polskiego, 1981, t. 3, PWN, Warszawa.

Stalończyk I., 2014, Edukacja formalna $i$ pozaformalna $w$ procesie ksztattowania społeczeństwa wiedzy, „Nierówności Społeczne a Wzrost Gospodarczy”, 37(1).

Szafraniec K., 2012, Szanse życiowe wiejskiej młodzieży, [w:] Wilkin J., Nurzyńska I. (red.), Raport o stanie wsi. Polska wieś 2012, Wydawnictwo Naukowe Scholar, Warszawa. 
Urbanikowa J., 2010, Ocena sytuacji $w$ szkolnictwie wyższym $w$ Polsce $w$ zakresie problematyki uczenia się przez całe życie ze szczególnym uwzględnieniem uznawania kompetencji zdobytych w sferze pozaformalnej z perspektywy Procesu Bolońskiego, ekspertyza na zlecenie Nauki i Szkolnictwa Wyższego, Warszawa, 23.03.2010, http://www.nauka.gov.pl/fileadmin/user_upload/Finansowanie/fundusze_europejskie /PO_KL/Projekty_systemowe/20101020_ekspertyza_podsumowanie_urbanik1.pdf (dostęp: 18.07.2013).

Zadrożniak M., 2015, Wyrównywanie szans edukacyjnych $w$ ramach polityki spójności jako kierunek poprawy jakości życia mieszkańców obszarów wiejskich $w$ Polsce, „Prace Naukowe Uniwersytetu Ekonomicznego we Wrocławiu”, 380, Wrocław.

Zieliński M., Gaura E., 2014, Wykształcenie jako element kapitału ludzkiego, [w:] „Organizacja i Zarządzanie”, 69, Zeszyty Naukowe Politechniki Śląskiej.

\section{Dokumenty strategiczne}

Europa 2020, Strategia na rzecz inteligentnego i zrównoważonego rozwoju sprzyjajacego właczeniu społecznemu, Komunikat Komisji Europejskiej, Bruksela 03.03.2010, KOM (2010) 2020, wersja ostateczna.

Narodowe strategiczne ramy odniesienia 2007-2013 wspierajace wzrost gospodarczy i zatrudnienie, 2007, Ministerstwo Rozwoju Regionalnego, Warszawa.

Opinia Sekcji rolnictwa, rozwoju wsi i środowiska naturalnego w sprawie ustawicznego ksztatcenia $i$ szkolenia zawodowego na obszarach wiejskich, Europejski Komitet Ekonomiczno-Społeczny, Bruksela 11.08.2015.

Program operacyjny Wiedza-Edukacja-Rozwój 2014-2020, Ministerstwo Infrastruktury i Rozwoju, Warszawa 17.12 .2014$.

Program rozwoju edukacji na obszarach wiejskich na lata 2008-2013, 2008, Ministerstwo Edukacji Narodowej, Warszawa.

Program rozwoju obszarów wiejskich na lata 2014-2020, 2014, Ministerstwo Rolnictwa i Rozwoju Wsi, Warszawa.

Rozporządzenie Parlamentu Europejskiego i Rady UE nr 1304/2013 z dnia 17 grudnia 2013 roku w sprawie Europejskiego Funduszu Społecznego i uchylające rozporządzenie Rady (WE) nr 1081/2006.

Strategia rozwoju kapitału ludzkiego 2020, 2013, Ministerstwo Pracy i Polityki Społecznej, Warszawa.

Strategia zrównoważonego rozwoju wsi, rolnictwa i rybactwa na lata 2012-2020, 2012, Ministerstwo Rolnictwa i Rozwoju Wsi, Warszawa.

Ustawa z dnia 27 lipca 2005 roku, Prawo o szkolnictwie wyższym (Dz.U., tj., 2012,art. 2, pkt. 1 , z późn. zm.).

\section{Źródła internetowe}

http://geopark-goraswanny.pl.

www.eip-agri.eu.

http://www.europarl.europa.eu/.

http://www.firmyrodzinne.pl/sites/default/files/szkolimy_dualnie.pdf.

$\mathrm{http}: / / \mathrm{www}$. ted.com/talks/ken_robinson_changing_education_paradigms.

http://www.unesco.pl/fileadmin/user_upload/pdf/4_Filary_Raport_Delorsa.pdf. 


\title{
THE IMPORTANCE OF TRANSFER OF KNOWLEDGE AND EDUCATION FOR RURAL DEVELOPMENT
}

\begin{abstract}
In the article there has been reflection on the possibility of transfer of knowledge and the use of new forms of education for inhabitants of rural areas. The main goal of this article was to show the importance of knowledge and education as essential elements of rural development. The subject matter of knowledge and education is invariably connected here, because through efficient education systems we gather knowledge, which we can later process, complement and create its new resources.

The article with the introduction consists of five parts. Initially, it was to analyze the concept and importance of knowledge and its diffusion for the development of rural population. Then, we investigated how the phenomenon of knowledge and education has been described in some documents of the EU, including rural areas. In the next part we examined the same issue, but in the perspective of selected documents at the national level (also with special emphasis on rural areas). In the fourth part we discussed some new forms of education and knowledge transfer feasible in rural areas. The final section presents modern information technologies possible to use in the process of education and knowledge transfer and provides examples of their use.
\end{abstract}

Key words: education, rural areas, the dual system, knowledge transfer, knowledge.

Dr inż. Brygida Klemens

Katedra Polityki Regionalnej

Wydział Ekonomii i Zarządzania

Politechnika Opolska 